\title{
ATHENS' SHADOWS
}

\author{
Victor Merriman \\ Edge Hill University \\ victor.merriman@edgehill.ac.uk
}

\begin{abstract}
This introductory essay attempts to communicate a sense of the articles and artist pages published in this Forum Kritika on Radical Cultural Responses to Crises in Urban Democracy, in the context of a symposium during which some of them were first argued. The contributors theorize relationships between art and protest, and the nature of performance, as well as critiquing interventionist performance projects, among dispatches from the front line of performance as public engagement. It also seeks to convey a sense of how culture-and especially performance-interacts, in Britain, with Project Austerity (2010-present). As culture and cultural workers, respond to neoliberalization, they are also increasingly shaped by its project of economizing public institutions, democratic processes, social services, and-some would argue-every social encounter. Influencing this critique is the mythos of Athens, asacross Europe-forces re-shape the democratic urban architecture which it has legitimised since the republican revolutions of the eighteenth century. It is in this context that artists struggle to conceptualize and enact a present public role.
\end{abstract}

\section{Keywords}

aesthetics, Athens, austerity, corporations, dignity, democracy, difference, drama, global city, Global North, Global South, Liverpool, migration, neoliberalization, oppression, Tate Liverpool, theater, political precariousness, postcolonial critique, precarity, slum, urban poor, urban regeneration, world city

\section{About the Author}

Victor Merriman is Professor of Critical Performance Studies at Edge Hill University. He is Director of the Performance and Civic Futures Research Group (2013-), and a founder member of One Hour Theatre Company (2016-). He publishes widely on the following topics: Irish theater, postcolonial criticism, public policy, pedagogy, and cultural theory. His monograph, Because We Are Poor: Irish Theatre in the 1990s, was published by Carysfort Press in 2011. 
He has edited special issues of the online journal Kritika Kultura (issues 14, 15 in 2010, and 21/22 in 2013) He was appointed a member of An Chomhairle Ealaion/The Arts Council of Ireland by Michael D Higgins, then Minister of Arts, Culture and Gaeltacht. In that capacity, he chaired the Review of Theatre in Ireland (1995-6). He is also a member of the National Council of the British Association for Irish Studies, as well as the international advisory board of Perspectives in the Arts and Humanities Asia. 
The desire to position a romantically ruined ancient Athens as the "secular Eden" of modern Europe (Shanks, 83-5) remains a culturally pervasive trope [but] the ancient city was more paranoid, more parochial, and much more precarious than idealising narratives allow.

Stephe Harrop, "Athens: A Work in Progress"

This Forum Kritika responds to In Athens' Shadow: Radical Cultural Responses to Crisis in Urban Democracy, a symposium held during Liverpool Biennial 2016. Tate Liverpool is a gallery devoted to making modern and contemporary art available to a broad public. The symposium program sought to interweave scholarly approaches to framing and interpreting cultural work in urban contexts, with accounts of specific urban activist projects taking place in the here and now of Liverpool, which was the European Capital of Culture in 2008. Convened by co-editor, Dr. Niamh Malone, Liverpool Hope University, and Lindsey Fryer, Alison Jones, and Jenny Collins, Tate Liverpool, In Athens' Shadow was chaired by Professor Victor Merriman, Edge Hill University. The contributions that follow, in "Radical Cultural Responses to Crisis in Urban Democracy" combine theoretical explorations of relationships between art and protest (Malcolm Miles) and the nature of performance (Alan Read), with critical accounts of interventionist performance projects (Michael D. Pante and Leo Angelo Nery; Niamh Malone), and dispatches from the front line of performance as public engagement (Gary Anderson and Lena Simic; Paula Currie; Jennifer Verson). Stephe Harrop's "Provocation" brings into play the radical instability of fifth-century Athens, grasped at a moment of work-in-progress, problematizing the city's received status as an enduring touchstone of liberal democratic thought and practice. Harrop's view of urban democracy as a series of contestatory practices, is significant as it counters a tendency to venerate Athenian institutions and those of the Enlightenment as fixed, enduring, and stable manifestations-even guarantors-of Western Liberal Democracy. As the European social democratic contract-so often symbolized in imagery drawn from Athens-is undermined by a hollowed out liberal state, the political, economic and psychic foundations of the lives of the 99 percent are literally undermined. Unsurprisingly, in this context, as economic precarity and political precariousness emerge in these pages as malign conjoined offspring of urban neoliberalization, Harrop's reminder that the iconic site of democracy itself was fraught with contradiction, is both timely and inspiring.

We owe an obvious debt of gratitude to our contributors, to Vincenz Serrano, and the editorial and production teams at Kritika Kultura, to the distinguished colleagues who undertook blind peer review of all contributions, and to all the contributors to In Athens' Shadow: Radical Cultural Responses to Crisis in Urban Democracy at Tate Liverpool. Professor Jen Harvie's memorable keynote contribution, The 
Housing Crisis is a Social Crisis, also helped to shape conversations which have resulted in this Forum Kritika. One of the key features of the original symposium was the presence, throughout the day, of interested members of the public, many of whom contributed to a lively and informative open discussion. This publication is an attempt both to record key problems and insights of those discussions and, under the good auspices of Kritika Kultura, to invite many others to raise their voices and join the discussion.

Athens is both a real, historic, place as well as a powerful trope, usually invoked to indicate enduring democratic values of civility, learning, mutual respect, negotiation, critique, and open government. The name, Forum Kritika, references the Athenian forum itself: a foundational site of public deliberation, and Kritika Kultura is a product of Manila's own "Ateneo," which is the Ateneo de Manila University. The origins of the University's name, according to its website, informs us,

Ateneo is the Spanish form of Atheneum, which the Dictionary of Classical Antiquities defines as the name of "the first educational institution in Rome" where "rhetoricians and poets held their recitations." [...] Hadrian's Roman school drew its title from a Greek temple dedicated to Athena, the goddess of wisdom, where, the Encyclopedia Britannica says "poets and men of learning were accustomed to meet and read their productions." Atheneum is also used to designate schools and literary clubs, a famous example of which is the Atheneum Angelicum, a Dominican center of learning in Rome. Its closest English translation is academy, pertaining to institutions of secondary learning. ("The Ateneo Name")

The contributions to this Forum Kritika reference contemporary urban sites, including Athens itself, Metro Manila, London, and Liverpool. London and Liverpool are replete with imposing neoclassical buildings citing the grandeur and civility of ancient Athens, and both are home to learned societies of prominent citizens, known as Athenaeum Clubs (Liverpool, founded 1797; London, founded 1824). These organizations, which house impressive libraries, valorise industry, knowledge, and artistic endeavour as profoundly social processes, under the patronage of Athena, Goddess of Wisdom. Thus, Athens and its lexicological derivatives cast shadows civic, aesthetic, and scholarly.

Liverpool was a world city before the fashionable idea of a global city (Sassen) seized the contemporary imagination. It remains a crucible of lived experience in which, over centuries, diverse and frequently oppositional human stories have been forged. Liverpool is perceived, in a profound sense, as a radical city (Belchem 
and Biggs), a function of the collisions, struggles, and solidarities that continue to characterise life on the banks of the River Mersey. Since England's neoliberal revolution began, in the late nineteen-seventies, civic and civil Liverpool has remained notably recalcitrant to its organizing tropes, continuing to value and assert social democratic principles of solidarity, openness, and mutual respect. Under funding withdrawals imposed from 2010 (Thorp), the city council has seen revenues decline at an extraordinary rate, raising fears that 2018 could see the city administration in bankruptcy (Ryan). A more general assault on the great cities of Northern England has led to extraordinary levels of low pay and underemployment, with accounts of the parlous condition of families using food banks in neighboring Birkenhead, reducing a Conservative member to tears in the British parliament (Kentish). This is the context in which the idea of a crisis in urban democracy becomes a matter for urgent consideration.

Events since the October 2016 symposium have rendered the naming and investigation of this crisis ever more urgent, as the neoliberal evisceration of the social democratic contract has intensified. Elected governments discipline, subjugate, and, as in Birkenhead, degrade and humiliate their own citizens, citing the "needs" of an economy functioning almost exclusively for the very wealthy as their driving imperatives. As these socio-political terms are globally recognizable, especially-for centuries - in the Global South, the dynamics of the crisis addressed by symposium participants, and in what follows, play out across today's world, differing only in longevity, degree, and local detail. In Athens' Shadow referenced the ancient democracy in relation both to Tate Liverpool's Biennale "Athens Event" and inherited ideas and institutions of a polis, currently under pressure. At the center of its concern, and in the essays and artist contributions to this Forum Kritika, stand artists and precarious urban communities-as interventionists, activists, and critical social actors. Like the societies out of which art forms emerge, and into which they play, such persons are historically compromised by economic and political forces, but are always available for thinking and acting otherwise.

\section{$* * *$}

In "The Case for Art, after the Era of Revolutions," his keynote address to the Tate Liverpool symposium, Malcolm Miles posed three practical roles for Art and aesthetics in dark times,

To expose contradiction

To envision alternatives, and

To configure, enable, and embody a refusal of the priorities of the regime, in

"acts of insubordination." 
Miles develops his argument here, in "Disobedient Cultures: Art, Politics, and Resurgent Hope," in which he revisits critical works on art and aesthetics by Herbert Marcuse. Miles considers urban galleries as self-justifying institutions, staging exhibitions that reflect, primarily, "the dominance of an art-world built on reputations, and a definition of the contemporary determined by an informal but strong consensus of dealers, curators, critics, collectors and successful artists." Miles argues further, that, for such elites, "the look counts most [so] the lived city is marginal to [their] enterprise culture." In this, the art-world operates as a kind of paradigm for trends toward social apartheid in global cities:

What people tend to do is spend more and more of their time around people who share a similar type of life-orientation, and that means that they're not spending as much time bumping into people who may view the world in a different way. That contributes to [the emergence of] a set of lifestyle bubbles that many people live in, and people that live in different kind of scenes become more subject to caricature and stereotype. (Silver) ${ }^{1}$

Responding to Silver, Laurie Taylor observed that the "bubbles" he describes "seem rather the opposite of a city as a diverse mass of people, in which different types of people rub along together." In contradistinction to such rarefied enclaves, urban streets stage everyday dramas of precarious living, characterized, in Miles's words, by "social atomism as well as multi-tasking and, for the lower paid, de-skilling."

Niamh Malone, and Michael D. Pante and Leo Nery, cite Henri Lefèbvre and Doreen Massey on the democratic potential of urban spaces, which Miles sees in their historical facilitation of "protest culture." Malone, and Pante and Nery engage with oppositional performances in which they locate what Miles calls "the potential insurgency of power-to in face of the dominant condition of power-over [by means of which] enactments in symbolic form interrupt and fracture the neoliberal illusion of inevitability." Malone posits urban spaces, historically, as sites negotiated by and for their inhabitants, between their concerns and the priorities of civil and civic institutions. She, and Pante and Nery see those negotiations displaced, in the regenerated global city model, by ideas and policies serving a concept of the city as destination for shopping, leisure, and entertainment. Branded and projected as a site of serene consumption, attractive to those enabled by disposable income, this is a city imagined and designed, and functioning primarily-in Pante and Nery's case study, only-as a marketplace. Malone's critical urban performers are part of a generation coerced into negotiating with economic precariousness in the rigged neoliberal economy of one of the world's richest Western countries. Duke Aid and Ghost Town conceptualise the forces of corporate consumerism, using embodied actions recalcitrant to "enterprise culture" to critique forces driving consumption, precarity, and their calamitous human consequences. In the Global South, Pante and Nery focus on exposing and asserting epistemologies forged in 
precarity's crucible, in cities in which, "the proletariat has become the precariat, a shift made spatially visible by urban slums teeming with the city's unemployed and underemployed." Furthermore, they ask, "[t]o what extent can we look at the slums of neoliberal cities in the Global South as spaces for the formation of revolutionary subjectivity?" In posing this question this way, they summon Europe's socialist ghosts to the discussion, citing, by implication, works by Brecht and Piscator depicting the factory as the site in which history is made by the working class (Willett). The slum was seen in the Global North of the early twentieth century, as a metaphor for destitution and inertia, as in the dismissal of Sean O'Casey's slum dramas:

In the Sunday Worker (by Huntly Carter) for showing 'man purposeless and on the drift', and it may be indicative of this that O'Casey never found a place in the [Workers' Theatre Movement] repertoire. T. A. Jackson (Sunday Worker, 24 June 1928) wrote of O'Casey's 'pessimism' as 'a fault that will disappear from the proletarian art of the future', while Carter referred to his dramatis personae as 'tenement defectives.' (Samuels et al. 54)

If neoliberalization has mandated urban poverty on an accelerated scale then, Pante and Nery's analysis of Gapok suggests that inherited social democratic emphases on a proletarian symbiosis of labour and struggle are challenged by the shift toward a precariat. If studies of the urban poor have concentrated on their economic plight, Pante and Nery expose a "political precariousness" under neoliberalization, arguably more detrimental to their aspirations to dignity and human flourishing.

In her Tate Liverpool symposium keynote address, "The Housing Crisis is a Social Crisis" (2016), Professor Jen Harvie argued for the political potential of Art's capacities for parody, ridicule, wit, and anger. Her approach recalls Cornel West's observation that cultural work always enacted in circumstances not of one's own choosing (31). She also positions critical cultural work as a means to demystify neoliberalized realities, and expose the human costs which they conceal. England's housing crisis reveals an established pattern of corporate behaviour toward young adults, reconfiguring them as suffering, infantilized denizens of the city, scarring their emotional health by means of economic privation and social isolation. Against this, "Art," Harvie argued, "can make things public," as in Sh!t Theatre's Letters to Windsor House (2016), a play for "Generation Rent," which raises the visibility, and exposes the social and emotional consequences of housing precarity. Sh!t Theatre created "a situation tragedy, not a sitcom," in order to disrupt the mediated domestication of housing precarity. Instead, it creates narratives and images with the potential to inspire movement toward "universal, decent, living conditions" in Britain, "[t]he data quantify the housing crisis; Letters to Windsor House shows its 
qualitatively human costs-how it infantilises people, paralyses them, denies them independence and growth, and strains the bonds of friendship" (Harvie, Foreword). Harvie concluded that this company, and this show both demonstrate the capacity of performance to expose and champion human needs, including the desires to which they give rise for decency, empathy, flourishing, and fair play.

Performance, in other words, can facilitate the emergence of conditions in which projects of "civil [and] civic repair" (Alexander 147) might be imagined and put into practice. Such projects are now urgently necessary, in the wake of the repudiation modernity's struggles over values, by the political economy of neoliberalism. Miles cited Antigone's defiance of Creon's assertion of state power, as a pointed example of the always inevitably compromised nature of radical struggle: her actions in repudiating state power are courageous beyond the point of folly, but the authority she invokes for her insubordination is that of religion and familyboth notoriously reactionary institutions. Struggle, as Terry Eagleton argued, is a matter of living through contradiction, and not a project of instantiating pure or perfect forms of human relations. Malone, Pante and Nery, and Paula Currie cite forms of performance in which actors embody resistance in their own persons, and appropriate theatrical form to radical purposes. The specific situations played out in Duke Aid, Ghost Town (Liverpool 2009; 2013), Gapok (Metro Manila 2016), Letters to Windsor House (London and touring 2015-2017), and Good Education (Liverpool 2014; 2015) are demonstrably different, but the dynamics underpinning these dramatic worlds join a common trajectory on "a path to poverty" (McCluskey). Pante and Nery consider one response to this situation in Gapok, a 17-minute oneact play, in which slum dwellers are presented in a parlous situation. "Gapok is an intense presentation of the socioeconomic contradictions faced by urban poor families. Gapok, which means brittle or fragile, similar to wooden structures eaten by termites, is a narrative of an urban poor family who engages with the social and economic pressures brought about by their precarious existence in the city". The play draws on Filipino performance values from the 1960s: "Instead of being performed in theaters that were inaccessible to the poor, these performances were brought to the streets, as theater became an instrument of political education" (quoted in Pante and Nery). Gapok draws also on traditions of working class theater recognizable in 1920 s and 1930 s Europe, and is a form of theater for the oppressed, in which the aesthetic, the minimalist set notwithstanding, is that of dialogue-driven social realism. Duke Aid's street performance is indebted both to live art interventions, and to the performative activism of Reverend Billy Talen and the Church of Stop Shopping Choir. Both Ghost Town and Letters to Windsor House return to more conventional dramaturgical forms, albeit infused with an eclectic set of performance modes. Good Education's dramaturgy is episodic, and its use of popular song, witty vernacular speech, and flexible staging, position it as an example of British popular theater, of a kind defined in John McGrath's A Good 
Night Out (1981). Good Education has in common with Gapok a commitment to the co-production of critical and creative work with working-class communities. In the case of Currie's play, the material is drawn from an archive of local memories of struggle to retain a neighborhood school in 1980 os Liverpool. The genesis of Alt Valley Community Trust-and of Good Education itself-in the prolonged and ultimately successful occupation of Croxteth Comprehensive bears out, in relation to solidarities born in common struggle, Miles's claim for the political efficacy of protest, that, "[w]hile each instantiation of refusal is ephemeral, their cumulative impact stretches the horizon of the possible [and] in the consciousness of those present, the once-widened horizon never closes in."

None of these performances conform to the conventions of mainstream commercial theater, and, in "We the Divided: Partitions of Performance in the Ceramic State," Alan Read argues a need to acknowledge the limits of the responsibilities cultural work and cultural workers might be expected to bear. Specifically, he advocates a sceptical-but not dismissive-stance toward claims made for the social efficacy of the evolved institutional theater, including avantgarde practices. He offers a richly textured meditation on theater itself, as a social problematic in these times: the preserve, in important respects, of "an exclusive, excluding profession." Hence, his scepticism regarding socially progressive claims made for theater, and his question as to why "theatre always fails its political ambitions." His analysis of Gob Squad's Revolution Now! (2010) is in tune with Jen Harvie's critique of contemporary performance practices in her Fair Play: Art, Performance and Neoliberalism (2013). "Exclusive and excluding," theater is a machinery of division, not political action, but paradoxically, Read argues, it retains the power to provoke responses to division, by staging moments of action on which to reflect. Division, which Read sees as synonymous neither with separation nor participation, serves the logic of an immunization paradigm, by which an organism is saved-immunized-from the contaminating gift of community; thus, theater is host to "the pathogen of performance." Nonetheless, theater retains social potential, in spite of its oft-foretold demise, although this is complicated by the embrace of the enduring conventions of the "ceramic state" (Athens, 500-300 BCE). Read concludes that the hegemony of two-dimensional ceramic form is affirmed in theater which shapes audiences as those who look on and wonder, in the presence of an "art of anti-emotion." Paradoxically, the impermeability of the stage image offers an experience of what it is to be divided, potentially countering possessive individualism.

Wendy Brown argues that neoliberalization repudiates the liberal democratic state's abiding commitment to providing for common human needs for shelter, learning, and nourishment, by hollowing out institutions designed to address those needs. Located in Croxteth, North Liverpool, Alt Valley Community Trust (AVCT) 
works to a dissenting model of alternative political economy, pursuing human flourishing by cultural activism. In "Towards a Democratic Theater: How Working Class Communities are Excluded from Mainstream Arts and Culture," Paula Currie, Creative Director of AVCT, exposes the playing out of tensions between activists-promoting human flourishing through creativity-and institutions, in which inherited obligations to enable this come into conflict with corporate imperatives. In AVCT's case, the struggle was with a major cultural institution in Liverpool, and Currie draws attention to the consequences for arts activism of the inundation of public service ethos by corporate culture, under earlier phases of neoliberalization. Corporations, notoriously, have succeeded in having themselves constituted in law as "persons" (Brown 154-72), and, in Currie's description, corporate behaviour appears as fearful and paranoid. An obsession with micromanagement and disciplined projection of company brands embeds anxieties around reputational damage, and enforces a bleached cult of risk aversion. Staff, trained to deal only with transactions which conform to the corporation's imagined self-interest, act as crude gatekeepers. Unusual ideas are read, not as innovations, but the special pleading of "difficult people," who must be kept at bay. "Training," as opposed to education, produces, it seems, a lamentable dearth of empathy, and a cavalier attitude to ethical practice. On this profile, an institution that operates as a corporation is a kind of adult baby, at the core of whose being is an individualist fantasy, begetting many unfortunate consequences, including territorialism. However, corporate institutions recognize themselves and their interests in each other and, territorialism notwithstanding, dog will not eat dog: if an employee is perceived as threatening the integrity of another brand, by advocating for a piece of critical art, for instance, a corporate institution will more than likely close ranks around that brand, reprimand the employee, and curb the dissenting gesture. Currie's account of her group's experiences resonates all too strongly with Read's description of an "exclusive and excluding" theater profession, and Miles's account of sealed "art-worlds." This indicates that some problems around dialogue with excluded groups reside, not only in theater's responses to neoliberalization, but also in the socially-compromised nature of professional theater.

If theater is among institutions open to critical attention by Read and Miles, Pante, and Nery argue a pressing need for auto-critical practice among researchers and scholars, "ethnographic representation (including this very paper) of the urban poor has to give way to new forms of knowledge production that involve their direct participation and unmediated articulation." In this, they shed light into one of the corners darkened by the idealised shadow of Athens: academic practice itself. To adapt Andy Hewitt and Mel Jordan as they are cited by Miles, "[s]cholarship is not benign; it is [...] deeply affected by political and ideological agendas. We believe in the possibility of scholarship's agency in the development and support of democratic systems." Moreover, "[t]he dominance of advanced capital makes it 
even more vital to maintain scholarship as a space for thinking and for contesting authority." This admonition of arts institutions and scholars, applies, in every particular, to artists, including activists. "Democracy Is Not Possible Here" is sub-titled, "a private argument in public," by Gary Anderson and Lena Simic, of the activist collective, the Institute for the Art and Practice of Dissent at Home (IAPDH). Their script foregrounds the present power of temptation, arguing the susceptibility of all, including radical activists, to renovated versions of modernist mythologies of origin and progression, and to the lure of profit, however modest. It is an ethical imperative for cultural workers to bear this in mind, as "Capitalism is not a mode of production anymore. It's a global style of life, a global ontology. It's an entity that in fact encompasses all our lives and relations with others and with nature" (Boaventura de Sousa Santos, in Sian 79). Refusing seduction by the "priorities of the regime" as in the stance of activists encountered by IAPDH in Green Park (Athens 2015), dissents from available futures in a strategic enabling gesture toward a better world. "Democracy Is Not Possible Here" prowls the boundaries of participation itself, arguing that this core feature of radical arts practice is heavily compromised while the internalized psychic architecture of neoliberalism remains - and remains unexamined-within, and by, activists themselves.

Anderson and Simic insist that, in critical interventionist performance practice, " $[t]$ here needs to be an underlying assumption about difference, not an underlying assumption about equality. We're not equal, we're different." Quite apart from its restatement of a generalizable progressive position, this ethical injunction is rooted, both in the constitution of IAPDH itself, and in England's contemporary cultural warfare. Since its foundation, IAPDH has treated Liverpool, England, Europe, and the World as imaginaries and actual locations in negotiation with lived experience of place, displacement, and solidarities. Their projects anticipate, in critical practice, democracy's need for an agonistic art of the building site (see Harrop). In “Migrant Artists' Mutual Aid: A Short History In Images," Jennifer Verson, who is an American living and working in Liverpool, references one such project:

In 2011 Lena Simic invited me to work with her on her "Becoming British" project we worked together to devise a new performance "Blood \& Soil: We were Always Meant to Meet..." a complex performance piece that traced the embodied reality of memories and dreams of migrant artists juxtaposed with the reality of "Life in the UK" test-an obligatory test for all immigrants applying for British citizenship and for "Indefinite Leave to Remain."

Simic, who is Croatian, and Verson's performance, at West Everton Community Centre, Liverpool pointed toward ways in which an agonistic art might negotiate 
terms of engagement with, for instance, British Values, a state discourse in which multiple anxieties about national identity crystallize (see Simic). The performance entailed a room full of local people, and Simic's university colleagues and students, collectively completing the Life in the UK test. While the test was taken, Simic and Verson moved through the room, reading autobiographical fragments from their ongoing dialogue:

The audiences' emotions, memories and anxieties evoked by test taking are part of the performance text. These memories enable a cognitive and real time experience of the process which an immigrant must deal with. This shared experience holds within it a seed of potentiality for mapping of a radically inclusive British identity. This 'new identity' in turn, holds the potential to transcend the historic problematic of equating nationalism and citizenship with racial/genetic identity. (Simic)

Since 2011, anxieties about Otherness have intensified across Europe and, in particular ways, in Britain. It is generally accepted that perceptions of "uncontrolled" immigration into Britain played a significant part in mobilizing a narrow but decisive, majority vote to withdraw from the European Union in 2016. Alan Read arrived in Athens as the result was announced, and conflicting responses there, and among his own friendship groups, prompted disturbing questions as to who was in and who was out of England's imaginary, and who might, in future, be admitted to the polis in a country that had "taken back control." One thing is plain: England in 2018 honours Ancient Athens mainly in its confusion and argumentation (Graham). Public discourse has been degraded in line with most other aspects of collective living under neoliberalization, and an English nationalist self-image, heavily vested in aspirations toward a resurgent exceptionalism, is everywhere projected. In short, current circumstances mock Simic's aspiration "to transcend the historic problematic of equating nationalism and citizenship with racial/genetic identity."

One of the ironies of the situation, from our perspective, is that Britain now seeks to detach itself from the European Union: an organization imagined as a kind of fruition of processes originating in Ancient Greece. As this gets under way, questions identified by Harrop as motivating Greek Tragedy also return with a vengeance:

How do we justify going to war? How do we survive the rage, and the revenges, of those people our wars have damaged beyond repair? Does our duty to give shelter to refugees outweigh political self-interest? Does the incorporation of strangers pose a mortal threat to a community's integrity and security?

These dilemmas lie at the heart of everyday experiences of escalating racist abuse and violence in England, which are experiences felt most acutely by the "Wretched 
of the Earth" - those who seek asylum. Across Europe, the plight and presence of displaced individuals in mass migrations are parlous indeed. The position of the asylum seeker in contemporary Britain is one of such acute exclusion as to challenge the capacity, even of the idea of precarity, to communicate it. Harvie's "dark times, pressurising all forms of kinship" (2016) are, in Verson's (2016) view, characterized by a degraded concept of "compassion fatigue," leaving advocacy groups with new barriers to overcome, and new borders to negotiate. In Migrant Artists' Mutual Aid: A Shortened History in Images (2016), developed here for inclusion in this collection, Verson argued for a "post-compassion" aesthetics of "vernacular cosmopolitanism" to address this. One sequence of images from MAMA's "shortened history" depicts a series of moments from a workshop, in which pairs of participants, in intimate proximity to each other, repeat, "I give more than I take." This simple combination of gesture and phrase, spoken out of first-hand experience, publicly contests abusive narratives of "scroungers" and the "undeserving," so crucial to the intensification of neoliberalization under Britain's Austerity experiment (2010-present; see Merriman), injurious to the urban poor; lethal to displaced persons. Here, in a short episode, is that "dualism of passion and language" which Read locates in acts of theater.

Read's dualism is worth setting alongside Jeffrey C Alexander's "duality," by means of which "the vertical relationships of [a society's] non-civil spheres economic, political, religious, familial, ethnic, and scientific - are challenged by membership in a horizontal, civil 'environment' that in principle surrounds them." Alexander argues that, "even for a dominated and marginalised minority, [this] duality allows the possibility, in principle, of struggles for empowerment and incorporation" (147). He also suggests that histories such as those of the struggle for civil rights in the American South, demonstrate the power of agonistic cultural work "in enabling actual social change." One might add to this the power of communicative acts-centered on Steve Biko and Nelson Mandela-in raising consciousness of, not compassion for, and, ultimately, redressing the injustices, of Apartheid South Africa. Changed historical circumstances notwithstanding, these deliberations suggest that "acts of insubordination," "sceptical vision," "situation tragedy," and "vernacular cosmopolitanism," may be embraced as the next phase in the renewal of a powerful lineage of human critical activity, older, perhaps, than Athens itself. However compromised and conditionalized, contemporary cities are rooted in histories as demonstrably civil environments, in the sense attributed by Harrop to Athens, and horizontal relationships, characterized by free association and openness to others are generative sites for the development of new kinds of citizenship, as imagined by Anderson and Simic, as well as Verson.

Great obstacles remain to be confronted, outwitted, or both. Liverpool's experience demonstrates that Western liberal democracy has been pushed to a 
point of collapse by corporate forces growing in power, resources, and confidence, over the past four decades. Neoliberalization has largely evacuated forum, temple, and theater, as imaginaries of public life. A relentless discrediting of these institutions, at a symbolic level, has facilitated their occupation by masters of the agora. It is now apparent that the crisis in urban democracy which we seek to address has arisen due to intense pressure applied to social, political, and cultural practices and institutions grounded in ideas of a more or less sovereign public. One consequence of this is that people living in the Global North, sustained for centuries by crumbs from Empires' tables, have begun to experience "a kind of creeping generalizability of the condition [of precariousness]" (David Theo Goldberg, in Sian 41-2). Historically, during the long history of colonial occupation and resource extraction and in its aftermath, this condition has defined life for the majority in the Global South. As the history of Filipino popular theater outlined by Pante and Nery shows, cultural interventions have been among means used to survive, resist, and think beyond it. Perhaps Europeans dislocated by Austerity may find a new affinity with people living in the Global South, in the shadow of those Empires, and their successor's power formations.

Naomi Klein was inspired to write her seminal book, No Logo (2001) by the realization that, across the world, local environments were under siege from a corporate "assault on the three social pillars of employment, civil liberties and civic space" (xxi). This is the world in which cultural workers now struggle to intervene, and the contributions to this Forum Kritika have identified potential starting positions from which to do so. The question as to what shape potential solidarities born of incorporation into a global precariat might take is an open one, but its urgency is not "growing."

Amplifying Anderson and Simic's insistence on an ethics of difference, Verson and MAMA "begin with we [who] are so different from each other that we hope it is possible to see the self in us, to join us. The sound becomes action as the images enter the world and provide fuel for engagement with the democratic structures of the state that controls the migration of humans. The fuel helps us to enter into democracy, to challenge the racism and misogyny of the asylum system."

Postcolonial scholarship and critical social theory have long since identified systemic maladjustment to difference in state systems, including liberal democracies. In founding the Performance and Civic Futures Research Group at Edge Hill University (2013), at the launch of Forum Kritika on Performance and Domination (Issue 21/22), this author invoked the city as a site more amenable than the state to a prospectus of human flourishing. This I attributed to its physical scale and the scale of its democratic structures: Liverpool has five members of parliament, but ninety city councillors, for instance; it also has a directly elected mayor. As the 
state accelerated its transition from liberal to post-liberal polity, re-engagement with the urban, or local region, seemed urgent, possible, and potentially fruitful. However, Alan Read concludes "We the Divided" with a reminder of the historical, and arguably still available, potential of the state and its institutions to care; in the process redeeming the word "curation" from its association with elite arts practice, as critiqued by Malcolm Miles. Neoliberalization of the caring professions has exposed a sharp distinction between curation as "caring about" and "caring for": The former comes with connotations of empathy, ethical concern, intimacy and love; the latter can be reduced to a policy of gesturing toward-but not meetingneeds of vulnerable adults, for example, whose encounters with overworked and underpaid "care" workers are hyper-calibrated, micro-managed, and rationed. Still, Read argues, the very act of preserving and exhibiting artefacts of the ceramic age, in museums and galleries, points to state capacity and long-standing commitment to a form of curation, in caring about and for its people. This is the form of cultural response embraced by MAMA, which is also embodied in workshop exercises that embrace excluded participants in an expanded vision of everyday life-in-common.

Finally, these responses to crises in urban democracy, framed in relation to shadows cast by both mythic and historical accounts of democratic Athens, pose questions for legislators, scholars, and cultural workers. Scholarship, as Pante and Nery argue, must move toward the co-production of knowledge with the urban precariat. Their attention to epistemologies currently in formation in the most abandoned site of precariousness is prefigured in the work of Boaventura De Sousa Santos, quoted here:

[In the favela] I learned that, beyond academic knowledge, there were other kinds of knowledge, and beyond official law, there was informal, unofficial law. Ideas of human dignity and respect [...] were completely outside our lenses in academic life; these ideas were coming from people that were considered ignorant, marginal, illegal and so on, when in fact they were struggling for a dignified life in the most undignified conditions. (qtd. in Sian 66)

This is both an indictment of and an invitation to expand academic sensibilities, in dialogue with forms of knowledges now beginning, of necessity, to emerge in the Global North, as they have in the Global South. Scholarship interacts both with public policy and popular discourse and their frequently aligned social tropes. To imagine and then pursue a renewed public role for the academy, nuanced for these times, could make a considerable difference, not least by renovating ideas of a polis in the face of neoliberalization's "dehistoriciz[ing] the possibilities of an individual's subject position in relation to their horizons of possibility [and] completely eras[ing] the possibility, even, of being able to tell a structural story of how it is that the world has come to be what it is" (Goldberg 44-5). 
Speaking on research into child poverty by the Beatrice Webb Trust (Edge Hill University Institute for Public Policy and Professional Practice, June 2017), its director, Barry Knight, urged policy makers to "Stop thinking of technocratic, top-down fixes. Pursue instead warm transformative relationships between people. What saves children is love." And this is a call to artists also: All the papers collected here speak to an ethics of relationship, of communitas, however compromised by the will to immunitas, of risking division in order to embrace difference as the ethical foundation of a flourishing life-in-common. 


\section{Note}

1. Silver is Associate Professor of Sociology at the University of Toronto and coauthor, with Terry Nichols Clark, of Scenescapes: How Qualities of Place Shape Social Life. University of Chicago Press, 2016. 


\section{Works Cited}

Alexander, Jeffrey C. Performance and Power. Polity, 2011.

Belchem, John and Bryan Biggs, editors. Liverpool: City of Radicals. Liverpool UP, 2011.

Brown, Wendy. Undoing the Demos: Neoliberalism's Stealth Revolution. Zone Books, 2015.

Eagleton, Terry. Nationalism: Irony and Commitment. Field Day, 1990.

Graham, James. "Enemies, traitors, saboteurs: how can we face the future with this anger in our politics?"https://www.theguardian.com/commentisfree/2018/feb/17/languagepublic-social-media-politics-repercussions Accessed 17 Feb. 2018

Harvie, Jen. Fair Play: Art, Performance and Neoliberalism. Palgrave Macmillan, 2013.

-.. Foreword. Letters to Windsor House. Nick Hern, 2016a.

"In Athen's Shadow? Radical Cultural Responses to Crisis in Urban Democracy." Tate, http://www.tate.org.uk/whats-on/tate-liverpool/exhibition/liverpool-biennial-2016/ athens-shadow. Accessed 30 Oct. 2017

Kentish, Benjamin. "Tory MP breaks down in tears at Labour MP's story about family invited to a funeral just so they could eat." Independent, 5 Dec. 2017, http://www. independent.co.uk/news/uk/politics/tory-mp-heidi-allen-break-down-destitutionuniversal-credit-frank-field-parliament-a8093906.html. Accessed 22 Jan. 2018

Klein, Naomi. No Logo. Flamingo, 2001.

McCluskey, Len. "Millions Face a Choice Between Food or Heating." Mirror.co.uk, 18 Oct. 2012, https://www.mirror.co.uk/money/million-families-face-choice-between-11442587. Accessed 22 Jan. 2018

McGrath, John. A Good Night Out: Popular Theatre: Audience, Class and Form. Eyre Methuen, I98I.

Merriman, Victor. “Marking 'Austerity:' Critique, Purpose and Performance.” Kritika Kultura, vol. 2I/22, 20I3, pp. 373-396, https://journals.ateneo.edu/ojs/index.php/kk/article/view/ KK2013.02109. Accessed 22 Jan. 2018

Miles, Malcolm. "The Case for Art, After the Era of Revolutions." In Athens'Shadow, 2016, Tate Liverpool. Keynote Address.

Reverend Billy \& the Stop Shopping Choir, http://www.revbilly.com/. Accessed II Dec. 2017 Ryan, Frances. "In Liverpool, Tory cuts have brought a city and its people to breaking point." The Guardian, 23 Mar. 2017, https://www.theguardian.com/commentisfree/20I7/mar/23/ liverpool-tory-cuts-city-benefits-poorest. Accessed II Jan. 2018

Samuels, Raphael, Stuart Cosgrove, and Ewan McColl, editors. Theatres of the Left, I8801935: Workers' Theatre Movements in Britain and America. Routledge, I984.

Sassen, Saskia. The Global City: New York, London, Tokyo. Princeton UP, I99I.

Sh!t Theatre. Letters to Windsor House. Nick Hern, 2016.

Sian, Katy P., editor. Conversations in Postcolonial Thought. Palgrave Macmillan, 2014.

Simic, Lena. "Blood \& Soil: we were always meant to meet... (2011)." Lena Simic, https:// lenasimic.org/artsprojects/collaborative-arts-projects/becoming-british/. Accessed 18 Jan. 2018 
Taylor, Laurie. "The Sensory Landscape of the City." BBC Radio Thinking Allowed, http:// www.bbc.co.uk/programmes/boglocc2. Accessed 10 Jan. 2018

"The Ateneo Name." Ateneo de Manila University, http://www.ateneo.edu/ateneo-name. Accessed 8 Jan. 2018

Thorp, Liam. "Council budget cuts: What has Liverpool lost since 2010?" Liverpool Echo, 16 Feb. 2017, https://www.liverpoolecho.co.uk/news/liverpool-news/council-budget-cutswhat-liverpool-12613097. Accessed 22 Jan. 2018

West, Cornel. "The New Cultural Politics of Difference." Out There: Marginalization and Contemporary Culture, edited by Russell Ferguson, Martha Gever, Trinh T. Minh-ha, and Cornel West. Massachusetts Institute of Technology Press, 1992, pp. 19-38.

Willett, John. The New Sobriety, I9I7-I933: Art and Politics in the Weimar Period. Thames \& Hudson, 1978. 